University of Nebraska - Lincoln

DigitalCommons@University of Nebraska - Lincoln

Journal for the Advancement of Developing

Economies

Economics Department

2013

Determinants of Savings Rate in Rural Nigeria: A Micro Study of

Kwara State

Oluwakemi Adeola Obayelu

University of Ibadan, Nigeria, jkemmyade@yahoo.co.uk

Follow this and additional works at: https://digitalcommons.unl.edu/jade

Part of the Econometrics Commons, Growth and Development Commons, International Economics

Commons, Political Economy Commons, Public Economics Commons, and the Regional Economics

Commons

Obayelu, Oluwakemi Adeola, "Determinants of Savings Rate in Rural Nigeria: A Micro Study of Kwara State" (2013). Journal for the Advancement of Developing Economies. 22.

https://digitalcommons.unl.edu/jade/22

This Article is brought to you for free and open access by the Economics Department at DigitalCommons@University of Nebraska - Lincoln. It has been accepted for inclusion in Journal for the Advancement of Developing Economies by an authorized administrator of DigitalCommons@University of Nebraska - Lincoln. 


\title{
Determinants of Savings Rate in Rural Nigeria: A Micro Study of Kwara State
}

\author{
Oluwakemi Adeola Obayelu \\ University of Ibadan, Nigeria
}

\begin{abstract}
The inability of households to save over time has significant influence on the rate of capital accumulation and economic growth in developing countries. In order to understand this trend, this research assesses savings rates and its correlates in rural Kwara state, Nigeria. A multi- stage sampling procedure was used to obtain data from 120 households. This was then analyzed using two descriptive statistics: the generalized linear model and the Tobit regression model. Results show that majority of the rural households were male-headed (81.0 percent) and combined farming with other non-farming activities (73.5 percent). The Tobit regression model reveals that age squared $(p<0.10)$, farming experience $(p<0.10)$ and diversification of non-farming activities $(p<0.05)$ positively influence rural saving rates.
\end{abstract}

\section{INTRODUCTION}

Poverty is a rural phenomenon in Nigeria (Obayelu, 2010). Owing to the low income of most of the rural people, it is difficult for them to survive, let alone save for investment. Providing affordable credit to the rural population has long been a prime component of development strategy. Savings are both a risk management strategy and a determinant of investment magnitude, but its determinants and mobilization strategy are controversial issues in literature (Mkpado \& Arene, 2010). In developing countries, where the majority of the population still has no access to state or market-based social security, savings is a means of strengthening social security systems (Jütting, 1999). The inability of rural entrepreneurs to access credit has restricted their potential to expand their enterprises; they cannot venture into non-farming activities, which results in low income and poor savings (Albu \& Scott, 2001). This has led to a low standard of living and the inability to break the vicious cycle of poverty for the rural dwellers.

The Nigerian financial system, like in many developing economies, consists of both the formal sector and a dominant informal sector. The dominance of informal sector is attributed to the underdeveloped nature of the country and the various structural rigidities in the economy that tend to restrain growth, savings and investment needed for enhancing the developmental process. A major characteristic of the Nigerian financial system is the existence of these two types of financial intermediaries operating side-by-side, a situation usually referred to as financial dualism. In spite of the recent upsurge in the number and activities of formal financial institutions and the subsequent high competition, the informal financial intermediaries still remain prominent (Oloyede, 2008). 
The informal financial institutions are more prominent in the rural settings and as such the rural populace (Aderinto et al., 2011). The informal financial institutions include: (1) the traditional savings and credit association (either rotating or non-rotating); (2) daily savings enterprises; and (3) professional money lending schemes. The key features of these informal schemes are savings and credit components, informality of operations, and higher interest rates in relation to the formal banking sector. Savings operate under different names such as esusu (among the Yorubas of South Western Nigeria), etoto (among the Igbos in the South East) and adashi in the North for the Hausas (CBN, 2000).

Existing empirical literature that analyzed savings behavior in Kwara state concentrated on agricultural financing (Aderinto et al., 2011; Orebiyi \& Fakayode, 2005) but household savings rates were not considered. Secondly, these studies focused on rural households that had savings, but did not include households with no savings. This created a selectivity bias in the data. This study therefore investigated the determinants of savings rate in the rural Kwara state with samples drawn from both households with and without savings. Earlier studies analyzed their data using the Ordinary Least Square regression model while this study employed the Tobit model, which is an econometric model with possible binary outcomes that assumes that the data is censored and truncated at zero.

\section{LITERATURE REVIEW}

Three traditional theories have been widely used in empirical studies on household saving behaviors in developed and developing countries. These are The Life Cycle Hypothesis (LCH) propounded by Modigliani (1963), the Keynesian Theory by Keynes (1936) and the Permanent Income Hypothesis (PIH) by Friedman (1957). The Life Cycle Hypothesis (LCH) states that the motivation of savings is to enable and ease lifetime consumption. Individuals save to prepare for their retirement when they will be unable to continue saving but continue to consume. An individual's savings will peak in his or her prime earning years and fall as the savings are drawn down to finance consumption during retirement years. Theoretically speaking, the marginal utility of consumption at a time of lower income is higher than that at a time of higher income (Gersovitz, 1995).

Keynes (1936) also identified absolute disposable income as an important determinant of saving. He defined savings as the amount left over when the cost of consumer expenditure is subtracted from the disposable income that he or she earns in a given period of time. Permanent Income Hypothesis (PIH) differentiates between permanent and transitory income and indicates that savings is influenced by both permanent and transitory income as well as present level of wealth, both human and nonhuman. In developing countries, like Nigeria, income plays a significant role in determining household savings. The desire and ability to save depends on having more than the resources dedicated to basic needs (Carpenter and Jensen, 2002). Recent studies have confirmed that savings is highly influenced by income (Browning \& Lusardi 1996; Pailwar et al. 2010). Browning \& Lusardi (1996) found that savings rates are higher for wealthy or more educated households. Likewise, savings rate increases with age until retirement and decreases after retirement.

Gersovitz (1995) identified several reasons as to why savings behavior in developing countries may diverge from saving patterns in developed countries. The reasons include: (a) households are 
dynastic and survive beyond individual members; (b) a household is an indecomposable unit and savings are decided at the household rather than individual level; (c) households have lower and more uncertain income; (d) borrowing constraints may be much more pervasive; and (e) savings provide a buffer for uncertain and unpredictable income rather than inter-temporal consumption smoothing. He also noted that families who earn low income from their rural farming or nonfarming enterprises have little or no savings when compared to farmers who earn high incomes from a combination of both farming and non-farming enterprises. However, the literature suggests the determinants of savings will include but are not limited to the income of the household.

Socioeconomic determinants of savings include age, gender of household head, level of education, size, farming experience, dependency ratio, type of occupation, household income, service charge, transport costs, credit access income, household loan repayment and amount of money borrowed (Adeyemo \& Bamire, 2005; Kibet et al., 2009; Pailwar et al., 2010). Several explanations have been offered of the effect of family size on household savings. On one hand, consumption theory explains that consumption is directly proportional to the number of household members. Literature from developed countries consistently displays a negative correlation between family size and household savings. Studies by Browning and Lusardi (1996), Loayza \& Shankar (2000), and Gardiol (2004) and Orbeta (2006) point out that large family sizes have lower household savings. Conversely, in developing countries, the intergenerational links of large families are particularly strong, which lengthen the effective planning horizon of households (Gersovitz1988) and reduce the need for savings for retirement or for intergenerational transfers (Deaton, 1991). Like many other issues, the empirical evidence on the impact of children on household savings is relatively scarce in developing countries (Schultz, 2005).

Furthermore, if wealth is in the form of productive assets such as livestock and farm land, it can have a positive impact on household savings (Khan et al., 2009). Larger land ownership helps the farmers benefit from economies of scale and, hence, higher production and earning. In contrast, Kulikov et al., (2007) concluded that there is no significant effect of real estate ownership on saving rates. Meanwhile, ownership of durable consumer goods, stocks of various financial assets and liabilities, as well as accessibility to liquid assets affects savings negatively.

\section{METHODOLOGY}

The multistage sampling procedure was used to collect data from Irepodun Local Government Area of Kwara State. The first stage of research was gathering samples from the Irepodun Local Government Area since it guaranteed a high share of agrarian rural individuals. It has an area of $737 \mathrm{~km}^{2}$ and a population of 148,610 at the 2006 census. Farming is the mainstay of the people's economy and is still practiced at a subsistence level. Commercial farming is limited to cocoa and oil palm plantations, large scale yam production, and maize and cassava cultivation. The second stage was the random selection of five wards in which people were actively involved in rural enterprises. At the third stage, two villages from each ward were randomly selected to ensure adequate representation of each ward. For the fourth stage, households in each village were randomly selected. Since decisions on savings are likely to be made at the household level, we aggregated the individual savings observations accordingly. We thus considered the household as our unit of observation. In all, a total of 120 household heads were sampled of which 116 provided consistent responses. The sampling technique was designed to ensure adequate representation of 
each category thereby providing greater reliability and ensuring the precision of the sample estimate.

\section{Analytical Techniques}

The savings rate of the households was expressed as:

Savings rate $=\underline{\text { Total income }- \text { Total Expenditure }} \times 100$

\section{Total income}

Descriptive statistics were then used to profile the savings rate of the socio-demographic characteristics of the rural households.

The Tobit regression analysis was used to identify factors determining savings rate. It is a nonlinear model and similar to the probit model. It is estimated using maximum likelihood estimation techniques. The dependent variable is normally distributed with mean $\mu$ and variance $\sigma^{2}$. The likelihood function for the Tobit model is:

$$
\log L=\sum_{\gamma_{i}>0}-\frac{1}{2}\left[\log (2 \pi)+\log \sigma^{2}+\frac{\left(Y_{i}-\beta X_{i}\right)^{2}}{\sigma^{2}}\right]+\sum_{\gamma_{i}=0} \log \left[1-F\left(\frac{\beta X_{i}}{\sigma}\right)\right]
$$

The function has two components:

1.) The probability density function for non-censored observations and

2.) The cumulative density function for censored observations. Censoring takes place when data on the dependent variable (regress and) is lost or limited but when data on the independent variables is not. In this case, the censoring point is at the lower limit (zero). The marginal effect is the change in $X i$ on $Y$, the unobservable latent variable.

The implicit form of the Tobit model is presented as:

$$
\mathrm{Y}=\mathrm{f}(\mathrm{Xi}, \mathrm{Ui}) \quad(\mathrm{i}=1,2,3, \ldots, \mathrm{n})
$$

Where: $\mathrm{Y}=$ Household savings rate; $\mathrm{X} 1$ = exogenous variables; $\mathrm{Ui}=$ error term. The expected signs of the regressors (independent variables) are presented in the appendix.

\section{RESULTS AND DISCUSSION}

The summary statistics are presented in Table 1. Results showed that the average age of the household heads was 50 years suggesting that the household heads were in their working age. The average household had ten members. Also, the average years of farming experience of household was 17 years which implied that a typical household head is well experienced with farming activities. The average income earned from crop production stood at N25,353.46 per month, which was higher than the average income earned from livestock (N4,814.65) and non- farming activities (N23,945.68). Similarly, the average monthly food expenditure (N30,392.58) was higher than nonfood expenditure $(\mathrm{N} 9,642.24)$. In addition, the average savings rate of the households was 0.21 percent indicating a low savings rate likely due to large family sizes and high expenditure on food. 
Table 1: Summary statistics

\begin{tabular}{llllll|} 
Household characteristics & $\mathbf{N}$ & Minimum & Maximum & Mean & Std Deviation \\
Age of Household head & 116 & 30.00 & 70.00 & 50.62 & 7.63 \\
Income from crop production & 116 & 0.00 & 110000.00 & 25353.46 & 28113.82 \\
Income from livestock & 116 & 0.00 & 120000.00 & 4814.65 & 18056.25 \\
Income from non-farm & 116 & 3000.00 & 151000.00 & 23945.68 & 17866.28 \\
Expenditure on non-food & 116 & 500.00 & 50000.00 & 9642.24 & 7723.14 \\
Expenditure on food & 116 & 11200.00 & 99200.00 & 30392.58 & 17436.56 \\
Household size & 116 & 0.00 & 25.00 & 9.71 & 4.70 \\
Farm experience & 116 & 0.00 & 43.00 & 17.69 & 12.77 \\
Savings & 116 & 0.00 & 80000.00 & 13605.60 & 16499.05 \\
Saving rate & 116 & 0.00 & 0.69 & 0.21 & 0.16 \\
& & & & & \\
\hline
\end{tabular}

As Table 2 illustrates, results revealed that $98.3 \%$ of the household heads were involved in personal savings while 68.1 percent of household heads saved in the banks. Also, about half of the respondents saved with cooperative societies. A potential reason for the high number of households with personal savings is because of easy accessibility to savings for immediate use. The results also show a moderately high level of formal savings with both banks and cooperatives among the rural households. Having formal savings in banks and cooperatives may increase their access to formal loans and boost their levels of rural enterprises.

Table 2: Type of Savings

\begin{tabular}{l|l|l|}
\hline Where household saves & Frequency & Percent \\
Self & 114.0 & 98.3 \\
Rotatory & 26.0 & 22.4 \\
Bank & 79.0 & 68.1 \\
Cooperatives & 61.0 & 52.6 \\
Daily savings & 42.0 & 36.2 \\
Others & 16.0 & 13.8 \\
\hline
\end{tabular}

Age of the head of the household is an important factor in determining the rate of savings by a household. The study revealed that 65.60 percent of household heads below 45 years of age could not save above 20 percent of their disposable income while about 54.2 percent of household heads within between the ages 45 to 65 years saved above 20 percent of their disposable income. This trend is outlined in Table 3. Conversely, all household heads above 65 years saved 21 to 40 percent of their disposable income. The observed high level of savings among household heads between (45 and 65 years old) suggests that the household heads were able to save more because they were in their economically active age bracket. This result is consistent with life-cycle hypothesis that the individuals in their middle age save more than their older and younger counterparts. However, their savings decrease as they attain old age. 
Table 3: Savings Rate and Age

\begin{tabular}{l|lllccc}
\hline \multicolumn{1}{c|}{ Savings rate (\%) } & \multicolumn{2}{c}{ Age in years } \\
& \multicolumn{2}{|c}{$30-45$} & \multicolumn{2}{c}{$46-65$} & \multicolumn{2}{c}{$>65$} \\
& Freq & $\%$ & Freq & $\%$ & Freq & $\%$ \\
$0.00-0.20$ & 21.0 & 65.6 & 38.0 & 45.8 & 0.0 & 0.0 \\
$0.21-0.40$ & 8.0 & 25.0 & 26.0 & 31.3 & 1.0 & 100.0 \\
$0.41-0.60$ & 3.0 & 9.4 & 15.0 & 18.1 & 0.0 & 0.0 \\
$0.61-0.80$ & 0.0 & 0.0 & 4.0 & 4.8 & 0.0 & 0.0 \\
Total & 32.0 & 100.0 & 83.0 & 100.0 & 1.0 & 100.0 \\
\hline
\end{tabular}

Table 4 shows that a higher proportion of female household heads (59.1 percent) had low savings rate of ( $\leq 20$ percent) while a higher proportion of their male counterparts saved above 20 percent of their disposable income. This suggests that female-headed households with lower savings rate are not likely to increase their scale of investments, unlike their male counterparts. This is because women hold lower levels of wealth and have significantly lower earnings than men (Fisher, 2010). Thus, in order to improve the savings rate of women in rural areas, their level of income should be raised through improved access to productive assets.

Results also revealed that savings rates fall when household size increases, as seen in Table 5. About 55.7 percent of households with ten or fewer members had more than 20 percent savings rate while about 60 percent and 100 percent of households with 11 to 20 members could not save above 20 percent of their income. This is probably because additional family members will expose these rural families to the risk of income deficiency, especially for poorer households. They also deprive households of the prospect of exploiting investment opportunities that come their way. At the aggregate level, additional children contribute to the reduction in savings rates, further depressing the already low savings rates of the country (Orbeta 2006). As a result, savings rate decreases with increasing household size.

Table 4: Savings rate and Gender

\begin{tabular}{|c|c|c|c|c|}
\hline Rate $(\%)$ & \multicolumn{4}{|c|}{ Gender } \\
\hline & & & & \\
\hline & Freq & Percent & Freq & Percent \\
\hline $0.00-0.20$ & 46.0 & 48.9 & 13.0 & 59.1 \\
\hline $0.21-0.40$ & 27.0 & 28.7 & 8.0 & 36.4 \\
\hline $0.41-0.60$ & 17.0 & 18.1 & 1.0 & 4.5 \\
\hline $0.61-0.80$ & 4.0 & 4.3 & 0.0 & 0.0 \\
\hline Total & 94.0 & 100.0 & 22 & 100.0 \\
\hline
\end{tabular}

Table 6 shows that a larger proportion of household heads with not more than 10 years of farming experience ( 85.7 percent) and those with 11 to 20 years of farming experience (62.5 percent) could not save more than 20 percent of their disposable income. However, a larger proportion of household heads with more than 20 years of farming experience (66.7 percent) saved more than 20 
percent of their disposable income. This trend is probably because years of farming experience could produce increased productivity and higher income and, consequently, lead to higher savings.

Table 5: Savings rate and Household Size

\begin{tabular}{|c|c|c|c|c|c|c|}
\hline \multirow[t]{3}{*}{ Rate (\%) } & \multicolumn{4}{|c|}{ Household size } & & \\
\hline & \multicolumn{2}{|c|}{$<10$} & \multicolumn{2}{|c|}{$11-20$} & \multicolumn{2}{|c|}{$>20$} \\
\hline & Freq & Percent & Freq & Percent & Freq & Percent \\
\hline $0.00-0.20$ & 31.0 & 44.3 & 27.0 & 60.0 & 1.0 & 100.0 \\
\hline $0.21-0.40$ & 23.0 & 32.9 & 12.0 & 26.7 & 0.0 & 0.0 \\
\hline $0.41-0.60$ & 13.0 & 18.6 & 5.0 & 11.1 & 0.0 & 0.0 \\
\hline $0.61-0.80$ & 3.0 & 4.3 & 1.0 & 2.2 & 0.0 & 0.0 \\
\hline Total & 70.0 & 100.0 & 45.0 & 100.0 & 1.0 & 100.0 \\
\hline
\end{tabular}

Table 7 shows that the highest proportion of household heads ( 60.0 percent) who were members of households that save, saved more than 20 percent of their disposable income while a larger proportion of those who were not members of a households that save (62.5 percent) did not save above 20 percent of their disposable income. Table 7 indicates membership of savings societies could promote savings and investments guaranteeing access to loans with or without collateral.

Table 6: Savings rate and Farming Experience

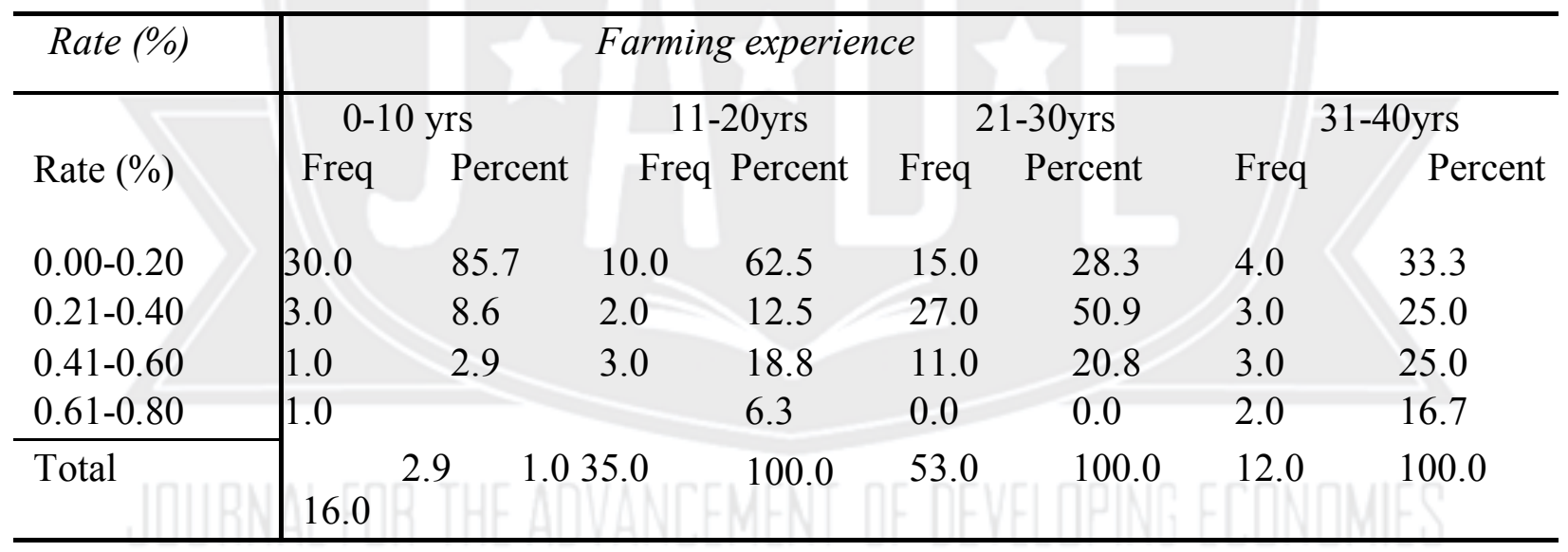

Table 7: Savings rate and Membership of Savings

\begin{tabular}{l|lllc}
\hline Rate (\%) & \multicolumn{3}{c}{ Members } & Non-members \\
& Freq & Percent & Freq & Percent \\
$0.00-0.20$ & 24.0 & 40.0 & 35.0 & 62.5 \\
$0.21-0.40$ & 17.0 & 28.3 & 18.0 & 32.1 \\
$0.41-0.60$ & 15.0 & 25.0 & 3.0 & 5.4 \\
$0.61-0.80$ & 4.0 & 6.7 & 0.0 & 0.0 \\
Total & 60.0 & 100.0 & 56.0 & 100.0 \\
\hline
\end{tabular}


Table 8 shows that about 52 percent of household heads that owned land saved more than 20 percent of their disposable income while about 80 percent of those who were not land owners could not save above 20 percent of their disposable income,. Households that owned land could increase a household's disposable income and savings by producing additional income in the form of rent. This trend is consistent with the conclusions of previous studies (Gonzalez-Vega, 2003; Lamberte et al., 2006; Komicha, 2007 and Pailwar et al. 2010) that if wealth is in the form of productive assets such as farm land it can have a positive impact on savings. Land ownership helps the farmers to benefit from economies of scale, higher production, and income. Secure land ownership is additionally a form of collateral for loans by the farmers. Credit, if utilized efficiently for improving land productivity, enhances the income level of the households, resulting in higher savings. , In conclusion, land ownership can significantly and positively affect savings rates of farm households.

Table 8: Savings rate and Land Ownership.

\begin{tabular}{l|lllc}
\hline Rate $(\%)$ & \multicolumn{3}{c}{ Land owners } & Non-land owners \\
& Freq & Percent & Freq & Percent \\
$0.00-0.20$ & 51.0 & 48.1 & 8.0 & 80.0 \\
$0.21-0.40$ & 33.0 & 31.1 & 2.0 & 20.0 \\
$0.41-0.60$ & 18.0 & 17.0 & 0.0 & 0.0 \\
$0.61-0.80$ & 4.0 & 3.8 & 0.0 & 0.0 \\
Total & 106.0 & 100.0 & 10.0 & 100.0 \\
\hline
\end{tabular}

Table 9 reveals that 51.8 percent of household heads that diversified their farming activities saved more than 20 percent of their disposable income while the same proportion of those who engaged in non-farm activities only could not save above 20 percent of their disposable income. The livelihood diversification into non-farming activities has the potential to increase sources of income, spread risks, and increase the rate of savings.

Table 9: Savings rate and diversification of enterprises.

\begin{tabular}{l|cccccc}
\hline \multirow{2}{*}{$\begin{array}{c}\text { Rate/diversification } \\
\text { in enterprises }\end{array}$} & \multicolumn{2}{|c}{ Farming only } & \multicolumn{2}{c}{ Non-farming } & \multicolumn{2}{c}{ Diversified Percent } \\
$0.00-0.20$ & Freq & Percent & Freq & Percent & Freq & Percent \\
$0.21-0.40$ & 0 & 0 & 18 & 58.1 & 41 & 48.2 \\
$0.41-0.60$ & 0 & 0 & 10 & 32.3 & 25 & 29.4 \\
$0.61-0.80$ & 0 & 0 & 3 & 9.7 & 15 & 17.6 \\
Total & 0 & 0 & 0 & 0 & 4 & 4.7 \\
\hline
\end{tabular}

\section{DETERMINANTS OF SAVINGS RATE}

The relationship between savings and its determinants was estimated using both the Generalized Linear model and the Tobit model (Table 10). The results show a similar trend in the results of both the Generalized Linear Model (GLM) and the Tobit model. The model was significant at one 
percent $(p<0.01)$ suggesting that all the independent variables jointly explain savings rates in the study area. The coefficients of interactions of savings rates with household size $(p<0.05)$, livestock share of income, $(p<0.10)$ primary occupation $(p<0.05)$, and food expenditure share $(p<0.10)$ were negative but positive for age squared $(p<0.10)$, farming experience $(p<0.10)$ and diversification into non-farming activities $(\mathrm{p}<0.05)$. The positive relationship between savings rates and age squared implies that the proportion of savings to total income increases as the household head grows older. These outcomes match the findings of Adeyemo \& Bamire (2005) and Orbeta (2006) but are inconsistent with the life cycle hypothesis of savings that a person is expected to save up to a point and then reduce the rate of savings as he or she grows older. Income is likely to be high during the Middle Ages when most of the household assets have been acquired and fear of a downward trend in the income upon retirement is present. Results also demonstrate that years of farming experience are positively related to savings rates. As farming experience increases, farmers are expected to be more efficient in their farm operations, earn more income and consequently increase their savings (Adeyemo \& Bamire, 2005). Interestingly, while farming as a primary occupation was negatively related to savings rates, diversification into non-farming activities was positively related to savings rate. These correlations exemplify the role of nonfarming activities in improving rural economy, investment, and savings rates. Similarly, human capital with education as a proxy measure shows a positive influence on households' savings rates.

In addition, a unit increase in household size, food share of total expenditure, and share of income from livestock would result in about 0.01 unit, 0.20 unit, and 0.26 unit decrease in savings rates. Additional family members will expose these rural families to the risk of income deficiency, especially within poorer households. They also deprive households of the prospect of exploiting investment opportunities that come their way. At the aggregate level, additional children contribute to the reduction in savings rates, further depressing the already low savings rates of the country (Orbeta 2006). Results show that the impact of additional children on household savings is negatively correlated. Although the per capita expenditure (permanent income) does not influence savings rate significantly, the results show that poor households save more, and rich households save less in response to an increase in investment opportunities. This is consistent with the findings of Bhalla (2002). The result also indicates that savings rates are negatively influenced by investment in livestock assets. Therefore, wealth accumulation in form of livestock will reduce the probability of savings in rural households.

Table 10: Determinants of savings rate of rural household heads

\begin{tabular}{|l|l|l|l|l|}
\hline & GLM & TOBIT & \\
\hline Variables & Coefficient & $\begin{array}{l}\text { OIM Standard } \\
\text { error }\end{array}$ & Marginal effect & Standard error \\
\hline Age squared & $0.0000611^{* *}$ & 0.0000256 & $0.0000622^{* *}$ & .0000247 \\
\hline Gender & -0.0430072 & 0.0420208 & -0.0420092 & .0404925 \\
\hline Hhsize & $-0.0089881^{* *}$ & 0.0039086 & $-0.0092429 * *$ & .003774 \\
\hline $\begin{array}{l}\text { Formal } \\
\text { education }\end{array}$ & -0.0592428 & 0.0583389 & -0.0612097 & .0562274 \\
\hline
\end{tabular}




\begin{tabular}{|c|c|c|c|c|}
\hline $\begin{array}{l}\text { Farm } \\
\text { experience }\end{array}$ & $-0.0044063 *$ & 0.0024703 & $-0.0043197 *$ & .0023847 \\
\hline Local institution & 0.0288042 & 0.0300457 & 0.026798 & .0290214 \\
\hline Landownership & 0.0210448 & 0.0762603 & 0.021008 & .0734839 \\
\hline Pre-occupation & $-0.1787545^{* *}$ & 0.0892506 & $-0.1809722 * *$ & .086004 \\
\hline Livestock share & $-0.2639148^{*}$ & 0.1504247 & $-0.2640307^{*}$ & .1449897 \\
\hline Diversification & $0.2693071^{* *}$ & 0.1083048 & $0.2677307^{* *}$ & .1044307 \\
\hline Food share & $-0.20209^{*}$ & 0.1149816 & $-0.2041084 *$ & .1108145 \\
\hline $\begin{array}{l}\text { Permanent } \\
\text { income }\end{array}$ & $-2.94 \mathrm{e}-06$ & $5.37 \mathrm{e}-06$ & $-2.91 \mathrm{e}-06$ & $5.17 \mathrm{e}-06$ \\
\hline $\begin{array}{l}\text { Diagnostic } \\
\text { statistics }\end{array}$ & $\begin{array}{l}\text { Scale paramete } \\
\text { Deviance = } \\
\text { (1/df) Devianc } \\
\text { Pearson } \\
\text { (1/df) Pearson } \\
\text { Variance funct } \\
\text { 1[Gaussian] } \\
\text { Link func } \\
\text { [Identity } \\
\text { AIC = - } \\
\text { Log likelihood } \\
\text { BIC = - }\end{array}$ & $\begin{array}{l}=0.0244612 \\
2.519505609 \\
=0.0244612 \\
2.519505609 \\
=0.0244612 \\
n: V(u)= \\
\text { on }: g(u)=u \\
7675125 \\
=57.51572491 \\
87.1003\end{array}$ & $\begin{array}{l}\text { LR chi2 }(12)=2 \\
\text { Prob }>\text { chi } 2=0 . \\
\text { Log likelihood }= \\
\text { Pseudo } R 2=0.3 \\
\text { sigma }=0.1494\end{array}$ & 570664 \\
\hline
\end{tabular}

\section{CONCLUSION}

The findings of the study suggest that increase in food share of total expenditure and household size would reduce savings rate. Thus, there is the need for the government to review its macroeconomic policies aimed at reducing rural consumer price index. The study also shows that encouraging birth control can help increase savings to protect families from income shortfall. This constitutes an important alternative to a formal safety net given the limited reach of the social security system. In order to help families avoid income shortfall, reproductive health policies should emphasize birth control among the rural populace. Results demonstrated that diversification into non-farming activities increased savings rates of the rural households. There is therefore the need to facilitate rural investment climate in order to enhance diversification into non-farming activities so that the level of income could translate into a higher level of savings rates and investments. The study found increased farming experience does not necessarily translate into increase in income. The outcomes point to the need to revamp the agricultural extension policy and programs which have the capacity to enhance the farmers' human capital development, 
improve their level of productivity, and raise their income and savings rate. By understanding these factors that influence savings rates to the formation, evaluation and implementation of policies and strategies, the Nigerian government and other interested stakeholders could improve the efficiency of the myriad of programs aimed at rural development.

\section{REFERENCES}

Abdelkhalek, T., Arestoff, F., Mekkaoui de Freitas, N., and Mage, S. (2009). A Microeconometric Analysis of Households Savings Determinants in Morocco. http://basepub.dauphine.fr/bitstream/handle/123456789/5550/A27CA046d01.pdf? sequence $=$.

Aderinto, A.A., Lawal, W.A. and Abdullahi, I.B. (2011). Determinants of Informal Agricultural Financing: Evidence from Rural Economy of Kwara State, Nigeria. The Journal of World Economic Review; Vol. 6(2):101-110

Adeyemo R., Bamire, A.S. (2005). Savings and Investment Patterns of Cooperative Farmers In Southwestern Nigeria. Journal of Social Sciences 11(3): 183-192.

Albu, M. and Scott, A. (2001). Understanding Livelihoods That Involve Micro-Enterprise: Markets and Technological Capabilities in the SL Framework. Warwickshire: Intermediate Technology Development Group.

Babatunde, R.O., Fakayode, S.B., Olorunsanya, E.O. and Gentry, R.A. (2007). Socioeconomics And Savings Patterns of Cooperative Farmers in South Western Nigeria. The Social Sciences 2(3): 287-292.

Bhalla, S.S. (1978). The Role of Sources of Income and Investment Opportunities in Rural Savings. Journal of Development Economics 5(3):259-281.

Bauer, T.K. and Sinning, M. (2005). The Savings Behavior of Temporary and Permanent Migrants in Germany. The Institute for the Study of Labor (IZA) Discussion Paper No. 1632

Bautista, R.M. and Lamberte, M.B. (1990). Comparative Savings Behavior of Rural and Urban Households in the Philippines. Philippines Institute for Development Studies Working Paper Series 90-15.

Brata, A.G. (1999). Household Savings Behavior: The Case of Rural Industry in Bantul. Analisis CSIS 28(1):75-86.

Browning, M. and Lusardi, A. (1996). Household Saving: Micro Theories and Microfacts. Journal of Economic Literature 34(4): 1797-1855.

Carpenter, S.B. and Jensen, R.T. (2002). Household Participation in Formal and Informal Savings Mechanisms: Evidence from Pakistan. Review of Development Economics, 6(3):314-328.

Central Bank of Nigeria (CBN) 2000. Annual Report and Statement of Account, CBN, Abuja.

Deaton, A. (1990). Savings in developing countries: Theory and teview. Proceedings of the World Bank Annual Conference on Development Economics 1989. Supplement to The World Bank Economic Review and the World Research Observer, May 1990, pp. 61-96.

Deaton, A. (1991). Savings and Liquidity Constraints, Econometrica, 59:1121-1142. Fisher, P.J. (2010). Gender Differences in Personal Saving Behaviors. Journal of Financial

Counseling and Planning 21(1):14-24

Friedman, M. (1957). A theory of the consumption function. Princeton: Princeton University Press. Gardiol, A.K. (2004). Les determinants de l'epargne et des choix d'investissement des ménages au Nicaragua, Departement d'Econometrie et d'Economie Politique, Universite de Lausanne, March. 
Gersovitz, M. (1988). Savings and development, in H.B. Chenery, and T.N. Srinivasan, (Eds.) Handbook of Development Economics (Vol. 1 pp. 382-424)). Elsevier Science Publishers.

Gersovitz, M. (1995). Savings and development. In: H. Chenery, and T.N. Srinivasan, (eds.), Handbook of Development Economics (Vol. 1 pp. 381-424)

Ghate, P.B. (1988). Informal credit market in Asian developing countries. Asian Development Review 6(1): 64-85.

Gonzalez-Vega C. (2003). Deepening rural financial markets: macroeconomic policy and political dimensions, paving the way forward. An International Conference on Best Practices in Rural Finance, Washington D.C, June.

Guariglia, A. (2001). Savings behaviour and earnings uncertainty: Evidence from the British Household Panel Survey. Journal of Population Economics 14(4): 619634.

Horioka, C.Y. and Wan J. (2006). The determinants of household savings in china: a dynamic panel analysis of provincial data. National Bureau of Economic Research (NBER) Working Paper 12723. Pp. 35

Iganiga, B.O. and Asemota A (2008). The Nigerian unorganized rural financial institutions and Operations: A framework for improved rural credit schemes in a fragile environment. Journal of Social Sciences 17(1): 63-71.

Issahaku, H. (2009). Determinants of savings and investment in deprived district capitals in Ghana -a case study of Nadowli in the Upper West region of Ghana. Continental J. Social Sciences 4(1): 1 - 12, 2011.

Jütting, J. (1999). Strengthening social security systems in rural areas of developing countries, ZEF - Discussion Papers on Development Policy No. 9, Center for Development Research, Bonn, June, pp. 44.

Khan, Z., Ullah, A. and Wahid, F. (2009). Intra rural regional difference in household savings: Empirical evidence from three rural areas of district Karak (Pakistan). Abasyn University Journal of Social Sciences 3(2):74-78.

Kibet, L.K., Mutai, B.K., Ouma, D.E., Ouma, S.A. and Owuor, G. (2009). Determinants of Household saving: Case study of smallholder farmers, entrepreneurs and teachers in rural areas of Kenya. Journal of Development and Agricultural Economics, 1(7): pp.137-143, October 2009.

Komicha, H.H. (2007). Farm household economic behaviour in imperfect financial markets: empirical evidence and policy implications on saving, credit and production efficiency in Southeastern Ethiopia, Doctoral Thesis, Swedish University of Agriculture Sciences, Uppsala.

Kulikov, D., Paabut, A. and Staehr, K. (2007). A microeconometric analysis of household Savings in Estonia: Income, wealth and financial exposure. Research Department Eesti Pank.

Keynes, J.M. (1936). The general theory of employment, interest and money. New York: Harcourt, Brace \& Co.

Lamberte, M.B., Vogel, R.C., Moyes, R.T. and Fernando, N.A (Eds.). (2006). Beyond Microfinance: Building inclusive rural financial markets in central Asia, Asian Development Bank.

Loayza, N. and Shankar, R. (2000). Private savings in India, The World Bank Economic Review, 14(3):571-594.

Mejeha, R.O. and Nwachukwu, N.I. (2008). Microfnance institutions in Nigeria. Munich Personal RePEc Archive (MPRA) Paper No. 13711, Online at http://mpra.ub.unimuenchen.de/13711/MPRA Paper No. 13711

Modigliani, F. (1963). The life-cycle hypothesis of saving: Aggregate implications and tests. American Economic Review, 53(1):55-84. 
Mkpado, M. and Arene, C.J. (2010). Does group design affect savings mobilization of rural Agricultural micro credit groups? Evidence from Nigeria. Economic Affairs 55(3/4): 231-242.

Muradoglu, G., Taskin, F. (1996). Differences in household savings behavior: evidence from Industrial and developing countries. The Developing Economies 24(2):138153.

NBS (2005). Poverty orofile for Nigeria. National Bureau of Statistics, Abuja. Nugroho, H. and Moeljarto, V. (1994). Debitur Potensial di Pedesaan Jawa. Prisma 9: 55-69.

Obayelu, O.A. (2010). Spatial decomposition of inequality and poverty in rural Nigeria.

Germany: Lap-Lambert Publishers.

Olashore, O. (1998). Perspectives on finance, banking and economic policy in Nigeria. Ibadan: Heinmann Education Books, Nig. Ltd..

Oloyede, J.A. (2008_. Informal financial sector, savings mobilization and rural development in Nigeria: Further evidence from Ekiti state of Nigeria. African Economic and Business Review 6(1):35-63.

Orbeta, A.C. (2006). Children and household savings in the Philippines. Philippine Institute for Development Studies, Discussion Paper, Series No. 2006- 14.

Orebiyi, J.S. and Fakayode, S.B. (2005). Determinants of savings mobilization by farmer cooperators in Kwara State, Nigeria. International Journal of Agriculture and Rural Development. IJARD. 6:66-73. Retrieved online at http://w ww//ajol/viewarticle.php?jid=12\&jd=24344

Pailwar, V.K., Kaur, J., Saxena, K., Nijhara, M. (2010). Impact of membership of financial Institutions on rural saving: A micro-level study. 2010 EABR \& ETLC Conference Proceedings. Pp. 610-618.

Reardon, T. (2000). Interactions between the agricultural system and non-agricultural activities of farm households in developing countries. In J.P. Colin and E.W. Crawford (Eds.) Research on agricultural systems: Accomplishments, perspectives, and issues (Pp 163-178). Huntington, NY: Nova. Science Publishers, Inc.

Schultz, T.P. (2005).Demographic determinants of savings: estimating and interpreting the aggregate association in Asia. IZA Discussion Paper No. 1479.

Yusuf, T.M. (2000). Socio - economic analysis of poverty level among rural dwellers in Kwara State, Nigeria, Unpublished M. Phil. Thesis in the Department of Agric. Economics, University of Ibadan.

\section{APPENDIX}

Table 11: Expected signs of the coefficients

\begin{tabular}{|l|l|l|}
\hline Variables & Expected signs & Literature \\
\hline Age squared & -ve & Abdelkhalek et al., 2009 \\
\hline Gender & -ve & $\begin{array}{l}\text { Abdelkhalek et al., 2009; Khan } \text { et al. } \\
(2009)\end{array}$ \\
\hline Hhsize & -ve & $\begin{array}{l}\text { Orebiyi and Fakayode (2005); Orbeta, } \\
2006\end{array}$ \\
\hline Formal education & $+\mathrm{ve}$ & $\begin{array}{l}\text { Guariglia 2001; Bauer and Sinning. } \\
(2005) ; \text { Browning and Lusardi (1996) }\end{array}$ \\
\hline Farm experience & Adeyemo and Bamire (2005). \\
\hline
\end{tabular}




\begin{tabular}{|l|l|l|}
\hline Local institution & $+\mathrm{ve}$ & $\begin{array}{l}\text { Pailwar } \text { et al. (2010); Babatunde et al., } \\
2007\end{array}$ \\
\hline Landownership & $\pm \mathrm{ve}$ & $\begin{array}{l}\text { Orebiyi and Fakayode (2005); Khan } \text { et } \\
\text { al. (2009); Abdelkhalek et al., 2009 }\end{array}$ \\
\hline Preoccupation & -ve & Kibet et al., 2009; Issahaku, 2009 \\
\hline Livestock share & \pm ve & Khan et al. (2009), \\
\hline Diversification & $+\mathrm{ve}$ & Khan et al. (2009) \\
\hline Food share & -ve & Carpenter and Jensen (2002 \\
\hline Per capita expenditure & $+\mathrm{ve}$ & $\begin{array}{l}\text { Bauer and Sinning (2005); Bhalla } \\
(2002) ; \text { Browning and Lusardi (1996) }\end{array}$ \\
\hline
\end{tabular}

